VOX PATRUM 25 (2005) t. 48

Ks. Adam M. FILIPOWICZ

(Warszawa, UKSW - WFCh)

\title{
POGLĄDY TERTULIANA NA TEMAT POCZĄTKóW ŻYCIA LUDZKIEGO I ABORCJI
}

1. W dyskusjach naukowych jak i potocznych nieustannie powraca temat życia poczętego, jego ochrony oraz warunków dopuszczalności przerywania ciąży na drodze tak zwanej aborcji. Istotny w polemikach okazuje się sposób, w jaki definiuje się samo życie, człowieka i moment jego poczęcia. Kwestie te budzą wiele kontrowersji i emocji, nie są jednak czymś nowym, charakterystycznym jedynie dla czasów współczesnych. Chociaż obecnie powracają one ze zwielokrotnioną siłą, były przedmiotem rozważań także minionych epok. Niniejsze opracowanie stanowi próbę przedstawienia w tym zakresie poglądów Tertuliana, apologety chrześcijańskiego z przełomu II i III wieku, którego pisma, jak zaznacza W. Turek, „ukazują niczym nieograniczoną ciekawość we wszystkich dziedzinach wiedzy, a jednocześnie doskonałą orientację w literaturze klasycznej, retoryce, historii, filozofii, naukach przyrodniczych, medycynie, psychologii i, w sposób szczególny, w prawie" ${ }^{1}$. W naszych rozważaniach bazować będziemy głównie na jego traktacie $D e$ anima ${ }^{2}$, w którym Afrykańczyk podejmuje polemikę, m.in. z poglądami fałszywej gnozy na temat duszy ${ }^{3}$ i przy tej okazji porusza interesujące nas zagadnienia. Obowiązkiem chrześcijan, jak podkreśla Tertulian, jest przeciwstawiać się błędom i wypaczeniom filozofów oraz heretyków, aby ustrzec pogan i wierzących przed pułapkami i sidłami błędnych teorii ${ }^{4}$. To wyznacza tematykę i celowość tego dzieła,

1 W. Turek, Tertulian, Opracowanie i wybór tekstów, OŻ 15, Kraków 1999, 19. Chodzi tu, jak pisze dalej W. Turek, „o prawdziwą kulturę, rozumianą w sensie formacji umysłu i ducha, pozwalającą na glęboką znajomość szeroko rozumianej rzeczywistości z możliwością nowych konstruktywnych wyjaśnień" (s. 20).

${ }_{2}$ Por. Tertullianus, De anima, ed. J. Waszink, CCL 2, 779-869; traktat ten pochodzi z okresu, kiedy Tertulian był już pod wpływem montanizmu.

${ }_{3}^{3}$ Por. F. Drączkowski, Patrologia, Pelplin - Lublin 1998, 133.

${ }^{4}$ Por. De anima 3, 3, CCL 2, 785: „Si qua igitur in hunc modum de nidoribus philosophiae candidum et purum aerem veritatis infuscant, ea erunt Christianis enubilanda et percutientibus argumentationes originales, id est philosophicas, et opponentibus definitiones caelestes, id est dominicas, ut et illa quibus ethnici a philosophia capiuntur, destruantur, et haec quibus fideles ab haeresi concutiuntur, retundantur". 
w którym Kartagińczyk wiele czerpie z filozofii stoickiej oraz odwołuje się do poglądów i autorytetu lekarza-ginekologa Soranusa z Efezu, autora nie zachowanego traktatu $O$ duszy (Peri psyches) $)^{5}$.

We wczesnym chrześcijaństwie, jak wskazuje J. Kosiewicz, wykształciły się, ścierające się ze sobą do czasów współczesnych, dwie przeciwstawne sobie tendencje w pojmowaniu ontologii czlowieka: jedna, oparta na orientacji orfickoplatońsko-gnostyckiej i druga, zakorzeniona w Starym i Nowym Testamencie ${ }^{6}$.

Czerpiący $\mathrm{z}$ orfizmu i platonizmu gnostycyzm podważał jakiekolwiek pozytywne znaczenie ciała w procesie zbliżania się do Boga, w człowieku akcentowano zatem przede wszystkim rolę duszy. Ciało rozumiane było jako przeszkoda i ograniczenie, przekleństwo człowieka oraz źródło wszelkiego zła i nieszczęść. Podkreślano głównie idealny i boski charakter duszy ludzkiej, dzięki której jednostka ludzka, spełniając wiele warunków, mogła osiągnąć szczęście i zbawienie. Taka wizja człowieka pogłębiała antropologiczną dwoistość i poszerzała rozziew między przyrodniczą strukturą podmiotu, jego związkami ze światem doczesnym a nadprzyrodzonymi właściwościami duszy, której głównym celem było jak najszybsze wyzwolenie się z okowów cielesności, aby zbliżyć się do Boga i osiągnąć zbawienie, pełnię niebiańskiej szczęśliwości w świecie bytów idealnych ${ }^{7}$. Powyższy nurt antropologiczny utrwalał i wzmacniał ontologiczny rozdźwięk między cielesnością a teocentryczną teologią duszy, której celem jest jedność z Bogiem.

Teksty Pisma Świętego wskazują wprawdzie na dwudzielny charakter ontologii człowieka, ale także na wzajemnie dopełniające się właściwości ciała i duszy, dwóch najistotniejszych komponentów jednostki ludzkiej. Drugi zatem kierunek $\mathrm{w}$ antropologii chrześcijańskiej zwany biblijnym, znosi fundamentalną nieprzystawalność oraz napięcie i dysharmonię pomiędzy ciałem i duszą. Zdaniem przedstawicieli tego punktu widzenia, zarówno ciało jak i dusza są niezbędne do spełnienia warunków, jakie Bóg stawia w drodze do zbawienia. Przyrodnicza odnowa, odrodzenie cielesne, a więc i zmartwychwstanie ciała jest konieczne, aby człowiek (ciało i dusza) mógł być kiedyś osądzony, nagrodzony lub ukarany za postępowanie w życiu doczesnym ${ }^{8}$.

${ }^{5}$ Soranus - lekarz i filozof z Efezu, żyl w I lub na początku II wieku w Rzymie, przedstawiciel szkoły zwanej Metodyczną; kwestie które podejmował w swym traktacie o ginekologii Gynaecia do dziś stanowią jej podstawę (por. O. Temkin, Soranus' Ginekology, Baltimore 1956); dzieło $O$ duszy w czterech księgach nie zachowało się, Soranus poruszał w nim problematykę nie tylko medyczną, ale także etymologiczną i odrzucał przeciwne poglądy filozoficzne. Tertulian powołuje się na niego kilka razy; por. M. Perrin, Un exemple de l'utilisation de la médicine chez les penseurs chrétiens: Tertullien et embryologie, w: Médicine antique, red. P. Demont, Amiens 1991, 91-110; R. Polito, I quatro libri sull'anima di Sorano e lo scritto „De anima” di Tertulliano, „Rivista di Storia della Filosofia" 49 (1994) 423-468.

${ }^{6}$ Por. J. Kosiewicz, Mysl wczesnochrzescijariska i katolicka wobec ciata, Warszawa 1998, 52-53.

7 Por. tamże, s. 52.

8 Por. tamże, s. 53. 
Wśród wczesnochrześcijańskich rozważań niełatwo jest wyróżnić poglądy, które można byłoby w pełni i bez wątpliwości przypisać do jednej bądź drugiej tendencji antropologicznej. Dochodziło bowiem do lączenia różnych trendów, założeń i interpretacji, niejednokrotnie ze sobą sprzecznych. Najczęściej występowały zatem refleksje o charakterze mieszanym, w których przeważała jedna bądź druga tendencja?

2. Tertulian zdecydowanie ukazywał człowieka jako ontyczną jedność duszy i ciała. To nie ciało stanowi człowieka, ani sama dusza, ale dopiero substancjalne połączenie obu tych elementów w jedno. Tak jak śmierć człowieka jest określana jako koniec życia poprzez rozdzielenie duszy i ciała, tak ich złączenie daje początek istocie ludzkiej i jest początkiem życia.

$\mathrm{O}$ początku życia ludzkiego Tertulian wnioskuje $\mathrm{z}$ jego końca:

„[...] skoro zaś przy śmierci rozłączenie obu substancji następuje równocześnie, zatem i przy ożywianiu połączenie ich musi się dokonywać według tej samej zasady, to jest równocześnie. Właśnie dlatego życie każdej istoty żywej zwykliśmy liczyć od momentu jej poczęcia, ponieważ od tego momentu przyznajemy jej duszę; odtąd bowiem istnieje dusza, odkąd i życie"10.

Swoją koncepcję antropologiczną Tertulian wyprowadza z Księgi Rodzaju, $\mathrm{z}$ opisu o stworzeniu człowieka ( $\operatorname{Rdz} 1,26-2,7)$. Istotna jest dobroć i miłość Boga objawiająca się w akcie stworzenia, jak również to, że Bóg osobiście formuje glinę i tchnie $w$ nią, powołując człowieka do istnienia i dając mu zarazem miejsce najwyższe w świecie. Pozwala to ukazać między innymi godność ciała ludzkiego ${ }^{11}$, a także entuzjazm i zachwyt nad ludzkim ciałem ${ }^{12}$.

Taka interpretacja pozwoliła naszemu autorowi, w odróżnieniu od innych pisarzy wczesnochrześcijańskich, przypisać ciału (uformowanemu z gliny przez samego Boga) jakość obrazu Bożego ${ }^{13}$. Stwórca jako wzór ma w rzeczywistości model mającego nadejść Chrystusa ${ }^{14}$ i gdy kształtuje ziemię (glinę), dzieło

${ }^{9}$ Por. tamże, s. 54.

${ }^{10}$ De anima 27, 2-3, CCL 2, 823: „si disiunctio simul utrique substantiae accidit per mortem, hoc debet coniunctionis forma mandasse pariter obvenientis per vitam utrique substantiae. Porro vitam a conceptu agnoscimus, quia animam a conceptu vindicamus; exinde enim vita, quo anima".

11 Por. Tertullianus, De resurrectione 6, 2-3, CCL 2, 927-928: ,adeo magna res agebatur quod ista materia extruebatur. Itaque totiens honoratur, quotiens manus Dei patitur, dum tangitur, dum decerpitur, dum deducitur, dum effingitur. Recogita totum illi Deum occupatum ad deditum, manu sensu opere consilio sapientia prouidentia et ipsa inprimis adfectione, quae liniamenta dictabat".

12 Por. tamże 9, 2, CCL 2, 932: ,absit, absit, ut Deus manuum suarum operam, ingenii sui curam, adflatus sui vaginam, molitionis suae reginam, liberalitatis suae heredem, religionis suae sacerdotem, testimonii sui militem, Christi sui sororem, in aeternum destituat interitum".

${ }^{13}$ Por. P. Siniscalco, Ricerche sul „De resurrectione” di Tertulliano, Roma 1966, 120.

${ }^{14}$ Por. Tertullianus, De resurrectione 6, 3-4, CCL 2, 928: „Quodcumque enim limus exprimebatur, Christus cogitabatur, homo futurus, quod et limus, et sermo caro, quod et terra tunc. Sic 
Boże (Dei opus) czyni to na Jego wzór, a on przez to staje się obrazem Boga

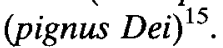

Tertulian bardzo często podkreślał prawdę, że Bóg stworzył świat z niczego i zgodnie $\mathrm{z}$ opisem $\mathrm{z}$ Księgi Rodzaju 2, 7 dusza ludzka pochodzi z Bożego tchnienia. Stworzenie świata według Tertuliana jest wyrazem miłości i dobroci Boga. W koncepcji gnostyka Marcjona, który negatywnie oceniał świat, Bóg poprzez działanie stwórcze objawił swoją złośćc ${ }^{16}$. Podejmując polemikę z Marcjonem w odrębnym dziele Adversus Marcionem, Tertulian podkreśla m.in., że to dobroć Boga powołała wszystko do istnienia i na początku wszystko było dobre. Ta sama dobroć stworzyła także człowieka, jego ciało, ale przede wszystkim duszę, która otrzymała życie, władzę i wolną wolę:

„[...] dobroć tchnęła i powstała dusza, nie martwa, ale żywa; i dobroć ją postawila nad wszystkimi stworzeniami, którymi miała się żywić, nad którymi królować, nawet je nazywać"17.

Dusza pochodząca od Boga stanowi o istocie i godności człowieka. Dzięki godności duszy jako tchnienia Bożego, człowiek jest obrazem i podobieństwem Boga, jest z Bożej substancji (substantia Dei $)^{18}$. To tchnienie Boga daje człowiekowi wolność woli i możność wyboru, co kwestionował Marcjon i gnostycy, a w czym według Tertuliana wyraża się największe podobieństwo człowieka do Boga:

,[...] przecież nie wyraża podobieństwa do Boga ani twarz, ani linie ciała - tak przeróżne u rodzaju ludzkiego, ale ta istota, którą otrzymał od samego Boga, to jest dusza, którą naznaczony jest na kształt Boga, bo ona zapewnia mu wolność jego sądu i możność wyboru"19.

Z faktu, że dusza przez tchnienie jest obrazem Boga wynikają jej właściwości, że jest m.in. bliższa Bogu niż materii, ale nie jest Bogiem i nie należy jej stawiać na równi z Bogiem:

enim praefatio patris ad filium: faciamus hominem ad imaginem et similitudinem nostram. Et fecit hominem Deus, id utique quod finxit, ad imaginem Dei fecit illum, scilicet Christi. Et sermo enim Deus, qui in effigie Dei constitutus non rapinam existimauit paria<ri> Deo"; zob. tenże, Adversus Praxean 12,3-4, CCL 2, 1173; Adversus Marcionem V 8, 1, CCL 1, 685. W cytowanych fragmentach wyraźne jest rozróżnienie, jakie czynił Tertulian na similitudo (podobieństwo) i imago (obraz). Pierwsze utracone przez człowieka na skutek grzechu pierworodnego, przywracane jest przez chrzest św., drugie trwa jako stałe jego uposażenie, por. De baptismo 5, 7, CCL 1, 282; De exhortatione castitatis 1, 3, CCL 2, 1015.

${ }^{15}$ Por. De resurrectione 6, 5, CCL 2, 928: „Ita limus ille iam tunc imaginem induens Christi futuri in carne non tantum Dei opus erat sed et pignus.".

${ }^{16}$ Por. Adversus Marcionem II 3, 2 - 4, 6, CCL 1, 477-479, thum. S. Ryznar, PSP 58, Warszawa 1994, 71-73, szczególnie nota 22.

17 Tamże II 4, 4, CCL 1, 479, PSP 58, 73.

18 Por. tamże II 5, 1, CCL $1,479$.

19 Tamże II 5, 6, CCL 1, 480, PSP 58, 74-75. 
„Przez to i obraz będzie mniejszy od prawdy i tchnienie niższe od Ducha, mając oczywiście w sobie owe linie Boga jako nieśmiertelnego, dusza zaś jako wolna w swoim wyborze, jako zazwyczaj przewidująca, jako rozumna, zdolna do rozumowania i do wiedzy. Jednakże $z$ racji tych właściwości pozostaje ona obrazem i nie dochodzi do samej potęgi Bóstwa, ani też nie jest nietykalna przez grzech, bo to należy do samego Boga"20.

3. Zagadnienia dotyczące określenia początków ludzkiego życia Tertulian porusza przy okazji omawiania kwestii pochodzenia duszy. W De anima 22, 2 określił duszę jako zrodzoną z tchnienia Bożego, ale jednocześnie jako pochodzącą od jednej tylko duszy prarodzica. Podejmuje tę problematykę, by wyjaśnić, „w jaki sposób wszystkie dusze pochodzą od jednej, kiedy, gdzie i na jakich zasadach biorą swój początek" ${ }^{21}$. Stawia zatem pytanie, czy dokonuje się to w lonie matki, czy poza nim, w momencie poczęcia, czy też narodzin dziecka, a może nawet później.

Tertulian najpierw przytacza poglądy Enesydemosa ${ }^{22}$ i stoików, którzy sądzili, że dziecko $w$ tonie matki jest jeszcze martwym płodem i dopiero w momencie narodzin otrzymuje duszę i życie:

„Twierdzą, że dusza nie zostaje poczęta w łonie matki i nie kształtuje się tam wraz $z$ organizmem cielesnym ani nie bywa wraz $z$ nim zrodzona, lecz dopiero po wydaniu płodu na świat zostaje wprowadzona $z$ zewnątrz $w$ nieżyjące jeszcze dziecko. Według nich nasienie przyjęte w akcie spółkowania przez organa niewieście kondensuje się rzekomo pod wpływem naturalnego ruchu w samą tylko substancję organizmu cielesnego; dopiero gdy ten opuszcza łono macierzyńskie parując jeszcze jego żarem, zostaje nagle owiany zimnym powietrzem, niby rozżarzone żelazo rzucone w wodę i pod wpływem tak gwałtownego wstrząsu nabiera od razu sił żywotnych oraz wydaje pierwszy głos" ${ }^{23}$.

Podobnie miał sądzić też lekarz Hikezjusz ${ }^{24}$, któremu Tertulian odmawia kompetencji, a także sam Platon:

${ }^{20}$ Tamże II 9, 4, CCL 1, 485: „In hoc erit imago minor veritate et adflatus Spiritu inferior, habens illas utique lineas Dei, qua inmortalis, [anima] qua libera et sui arbitrii, qua praescia plerumque, qua rationalis, capax intellectus et scientiae, tamen et in his imago et non usque ad ipsam vim divinitatis; sic nec usque ad integritatem a delicto, quia hoc soli Deo cedit, id est veritati", thum. PSP 58, 79.

${ }^{21}$ De anima 25, 1, CCL 2, 818-819: "uti reddam, quomodo animae ex una redundent, quando et ubi et qua ratione sumantur".

22 Enesydemos z Knossos, filozof grecki z I w. przed Chrystusem, przedstawiciel filozofii sceptycznej.

${ }^{23}$ De anima 25, 2, CCL 2, 819: ,[...] qui praesumunt non in utero concipi animam nec cum carnis figulatione compingi atque produci, sed et effuso iam partu nondum vivo infanti extrinsecus inprimi; ceterum semen ex concubitu mulieribus locis sequestratum motuque naturali vegetatum compinguescere in solam substantiam carnis; eam editam et de uteri fornace fumantem et calore solutam, ut ferrum ignitum et ibidem frigide immersum, ita aeris rigore percussam et vim animalem rapere et vocalem sonum reddere", thum. M. Michalski, ALP I 239.

${ }^{24}$ Hikezjusz - żył w 1. poł. I wieku przed Chrystusem, działał na polu farmakologicznym. 
„[...] z pierwszym oddechem dziecka zostaje w jego organizm wprowadzona z zewnątrz, spoza matczynego łona, dusza, która znów później wraz z ostatnim oddechem uchodzi z człowieka"25.

Jako podstawowy kontrargument dla tych teorii, Tertulian przywołuje świadectwa kobiet brzemiennych, które według niego jedynie są kompetentne, by na podstawie własnych doznań stwierdzić, że płód porusza się i żyje, a gdzie jest ruch i życie, musi być dusza. Kobieta czuje i cieszy się, gdy poczęte dziecko rusza się i przesuwa w łonie, jak reaguje na zewnętrzne dźwięki, jakby już coś słyszało. Także to, że organizm matki domaga się pewnych pokarmów, a przed innymi wzbrania, że urazy i choroby matki odbijają się na poczętym dziecku, są dowodem, że płód żyje ${ }^{26}$ :

„Skoro bladość lub rumieniec zależy od krwi, zatem gdzie jest krew, tam musi być i dusza; skoro zdrowie polega na przybywaniu energii witalnej, zatem gdzie jest zdrowie, tam musi być i dusza; skoro głód lub brak apetytu, wzrastanie lub zmniejszanie się, strach, ruch są objawami funkcji duszy, zatem niewątpliwie to, co owe funkcje wykonuje, żyje, bowiem kto je przestaje wykonywać, przestaje też życ”27.

Jako dowód na to, że płód jest już organizmem żywym, a więc musi posiadać duszę, Tertulian podaje fakt, że niekiedy dzieci rodzą się martwe: „bo co znaczy zmarłe, jak nie to, ze przedtem żyły?"28.

4. Istotnym dowodem na życie płodu, a więc także na posiadanie przez niego duszy, jest według Tertuliana zabijanie jeszcze w lonie matek dzieci poczętych:

„niekiedy nawet sami zabijamy dziecko (infans trucidatur) w lonie matki, rzecz niewątpliwie okrutna, ale konieczna, gdy poprzeczne położenie plodu uniemożliwia poród; jeśliby wówczas nie pozbawiono dziecka życia, stałoby się ono zabójcą swojej rodzicielki"29.

Tertulian używając czasownika trucidare jednoznacznie aborcję nazywa morderstwem dokonywanym na niewinnych dzieciach. Dopuszcza ją jednak

${ }^{25}$ De anima 25, 2, CCL 2, 819: ,animam extraneam alias et extorrem uteri prima adspiratione nascentis infantis adduci, sicut exspiratione novissima educi”, thum. Michalski, ALP I 239.

${ }^{26}$ Por. tamże 25, 3, CCL 2, 819.

27 Tamże 25, 4, CCL 2, 819-820: „Si livor ac rubor sanguinis passio est, sine anima non erit sanguis; si valetudo omnis accessio est, sine anima non erit valetudo; si alimonia inedia crementa decrementa pavor motus tractatio est animae, his qui fungitur, vivet. Denique desinit vivere qui desinit fungi", tłum. Michalski, ALP I 240.

${ }^{28}$ Tamże 25, 4, CCL 2, 820: „Qui autem et mortui, nisi qui prius vivi?”, thum. Michalski, ALP I 240.

29 Tamże 25, 4, CCL 2, 820: „Atquin et in ipso adhuc utero infans trucidatur necessaria crudelitate, cum in exitu obliquatus denegat partum, matricida, ni moriturus", thum. Michalski, ALP I 240. 
w sytuacji wyższej konieczności. Za taką uważa jedynie przypadek, kiedy poród staje się niemożliwy ze względu na niewłaściwe ułożenie dziecka w łonie i przez to wprost zagrażające życiu matki.

Nasz autor przy tej okazji wymienia także narzędzia zbrodni, jakimi posługiwali się ówcześni lekarze dokonujący aborcji:

„wśród narzędzi lekarskich znajduje się nie tylko instrument do otwierania siłą, przy pomocy ruchu obrotowego, części rodnych, nie tylko okrągły nóż do ostrożnego poodcinania w ich wnętrzu czlonków, nie tylko tępy hak do dokonania gwałtownego porodu i wyciągnięcia niebezpiecznego plodu, lecz także lancet $\mathrm{z}$ brązu do zabicia płodu, do popełnienia na ślepo morderstwa rabunkowego; zwie się ów lancet embriosfastes, jako że nim zabija się żywe dziecię"30.

Kartagińczyk wymienia również znanych lekarzy starożytnych, którzy w swej praktyce lekarskiej dokonywali aborcji. Nie zmienia to jednak okrutności samego czynu, przy którym paradoksalnie litość skłania do zabicia dziecka, by nie rozszarpywać go żywcem:

„Posiadal je [to narzędzie] i Hipokrates i Asklepiades i Erasistratos i Hierofil, który przeprowadzał również sekcje na dorosłych, a także znany $\mathrm{z}$ łagodności Soranus - a wszyscy w przeświadczeniu, że poczęty płód żyje i że tylko $z$ litości zbija się to nieszczęsne niemowlę, nie chcąc go żywcem rozszarpywać. O konieczności takiego mordu nie wątpił nawet wzmiankowany wyżej Hikezjusz, mimo że uważał, iż dusza wstępuje w zrodzony płód dopiero przy zetknięciu się go z zimnym powietrzem"31.

Sposób, w jaki Tertulian opisuje powyższe kwestie, pozwala sądzić, że dopuszcza on jedynie w skrajnych przypadkach dokonanie zabójstwa dziecka w łonie matki i to nie ze względu na wiedzę, ale stan i ograniczone możliwości ówczesnej medycyny.

Tertulian przytacza szereg dowodów na to, że płód jest żywym organizmem, który posiada duszę. Swiadczy o tym chociażby zabieg cesarskiego cięcia, dzięki któremu wydobywa się przecież z lona matek żywe dzieci:

${ }^{30}$ Tamże 25, 5, CCL 2, 820: „Itaque est inter arma medicorum et cum organo, ex quo prius patescere secreta coguntur tortili temperamento, cum anulocultro, quo intus membra caeduntur anxio arbitrio, cum hebete unco, quo totum facinus extrahitur violento puerperio. Est etiam

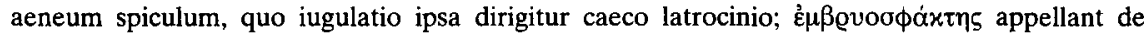
infanticidii officio, utique viventis infantis peremptorium", thum. Michalski, ALP I 240.

31 Tamże 25, 5-6, CCL 2, 820: „Hoc et Hippocrates habuit et Asclepiades et Erasistratus et maiorum quoque prosector Herophilus et mitior ipse Soranus, certi animal esse conceptum atque ita miserti infelicissimae huiusmodi infantiae, ut prius occidatur, ne viva lanietur. De qua sceleris necessitate nec dubitabat, credo, Hicesius, iam natis animam superducens ex aeris frigidi pulsu, quia et ipsum vocabulum animae penes graecos de refrigeratione respondens", thum. Michalski, ALP I 240. 
„[...] znamy dzieci, które po rozcięciu brzucha matki wydobyto żywe, jak było na przykład w przypadku Libera lub Scipiona"32.

Kartagińczyk ironizuje również z poglądów stoickich, że gdyby dzieci ożywały i otrzymywały dusze dopiero po narodzeniu, na skutek powiewu zimnego powietrza lub pierwszego oddechu, to niektóre narody winny być bardzo liczne, wśród innych zaś, w ciepłych krainach nikt nie powinien się rodzić, bo skąd czerpaliby dusze ${ }^{33}$.

5. Analiza przeprowadzana przez Tertuliana wskazuje, że pojawiały się twierdzenia kwestionujące życie płodu i posiadanie przez niego duszy, ponieważ uważano za niemożliwe w przypadku brzemiennej kobiety, aby dwie dusze zeszły się razem w jedno. Zarzut ten odrzuca nasz Autor dowodząc, że nie tylko w czasie ciąży jest możliwe połączenie dwu dusz i dwu ciał w jednym, ale także wielu dusz, a nawet demonów, czy duchów w każdym człowieku z osobna. Podaje przykład Sokratesa, Marii Magdaleny, w której przebywało siedem złych duchów (Mk 16,9) oraz Gerazeńczyka, w którym zamieszkiwał cały legion demonów (Mk 5, 1). Podsumowując stwierdza:

„[...] skoro połączenie ludzkiej duszy ze złym duchem, posiadającym inną niż ona naturę, jest możliwe, to chyba tym bardziej możliwe jest połączenie dwóch dusz o jednakowej substancji”,34.

Tertulian przywołuje także biblijne przykłady kobiet ukazując, że poczęte w ich tonach dzieci nie tylko oddychały, ale nawet prorokowały ${ }^{35}$. Oto bliźniaki Ezaw i Jakub, synowie Rebeki, już w łonie matki toczyli ze sobą walkę, będącą zapowiedzią przyszłych dwu wrogo usposobionych narodów ( $\mathrm{Rdz} 25,21-26$ ). Także w przypadku niepłodnej Elżbiety i dziewicy Maryi, w ich łonach za sprawą Boga poczynają się dzieci, które poruszając się okazują radość ze spotkania się ich matek (Łk 1, 39-55). Zatem żyją, mają nie tylko dusze, ale i ducha. Podobnie w przypadku proroka Jeremiasza, Bóg mówił: „Zanim ukształtowałem cię $w$ łonie matki, znałem cię, nim przyszedłeś na świat, poświęciłem cię" (Jr 1,5). Tertulian stwierdza, że Bóg nie może znać człowieka w lonie inaczej, jak tylko całego, a zatem żywego i z jego duszą, tym bardziej, że jest Bogiem żywch ludzi, a nie martwych ciał:

${ }^{32}$ Tamże 25, 8, CCL 2, 821: „possumus illos quoque recogitare qui exsecto matris utero vivi aerem hauserunt, Liberi aliqui et Scipiones", thum. Michalski, ALP I 241.

${ }^{33}$ Por. tamże 25, 6-7, CCL 2, 820-821: „[...] unde illis animam, quibus aeris rigor nullus? [...] si aeris rigor thesaurus est animae, extra Germanias et Scythias et Alpes et Argaeos nemo debuit nasci".

${ }^{34}$ Tamże 25, 8, CCL 2, 821: „[...] quo facilius anima cum anima conseretur ex societate substantiae quam spiritus nequam ex diversitate naturae", thum. Michalski, ALP I 241.

${ }^{35}$ Por, tamize 26, 1-4, CCL 2, 821-822. 
"[...] jeżeli Bóg kształtuje w łonie, to i tchnie jak pierwotnie: i utworzył Bóg człowieka i tchnął w niego tchnienie życia" $(\operatorname{Rdz} 2,7)^{36}$.

Tertulian wykazuje również niekonsekwencję Platonowi w poglądach, iż dziecko otrzymuje duszę dopiero po narodzeniu wraz z pierwszym oddechem, a w VI księdze Praw wyprowadza ją z nasienia ludzkiego ${ }^{37}$ - ostrzega tam bowiem, by przez nieodpowiednie współżycie nie uszkodzić nasienia, gdyż mogłoby to spowodować jakiś defekt na ciele lub duszy dziecka ${ }^{38}$. Potwier$\mathrm{dza}$ on, że duszę należy wyprowadzać $\mathrm{z}$ nasienia duszy rodziców. Dowodem tego ma być świadectwo Kleantesa o podobieństwie dzieci do rodziców pod względem charakteru ${ }^{39}$, jak też horoskopy starożytnych astrologów, wyprowadzane od momentu poczęcia człowieka, które w równej mierze odnoszą się do duszy ${ }^{40}$.

6. Po przedstawieniu dowodów na to, że dusza wywodzi się z nasienia duszy rodziców i posiada ją już poczęte dziecko, Tertulian przystępuje do omówienia konkretnych zasad, jak dokonuje się połączenie duszy i ciała poprzez poczęcie istoty żywej. Stwierdza, ze substancja ciała i substancja duszy (substantia corporis animaequae) powstają równocześnie bez jakiejkolwiek różnicy czasowej:

„Według nas obie substancje zostają równocześnie poczęte, kształtowane i utworzone, tak samo jak później obie równocześnie bywają wydane na świat: nie ma żadnej kolejności w czasie ich poczęcia" ${ }^{41}$.

Tak jak śmierć jest końcem życia poprzez rozdzielenie duszy i ciała, tak ich połączenie jest początkiem życia:

„[...] skoro zaś przy śmierci rozłączenie obu substancji następuje równocześnie, zatem i przy ożywianiu połączenie ich musi się dokonywać według tej samej zasady, to jest równocześnie. Właśnie dlatego życie każdej istoty żywej zwykliśmy liczyć od momentu jej poczęcia, ponieważ od tego momentu przyznajemy jej duszę; odkąd bowiem istnieje dusza, odtąd i życie" ${ }^{42}$.

${ }^{36}$ Tamże 26, 5, CCL 2, 822: „Si fingit Deus in utero, et afflat ex primordii forma: et finxit Deus hominem et flavit in eum flatum vitae".

${ }^{37}$ Por. Plato, Leges 775b-c.

38 Por. De anima 25, 9, CCL 2, 821: „At idem in sexto Legum monens cavere ne vitiatio seminis ex aliqua vilitate concubitus labem corpori et animae supparet [...]. Ostendit enim animam de semine induci, quod curari monet, non de prima aspiratione nascentis".

39 Kleantes z Assos w Troadzie (331-232), filozof ze szkoły stoickiej, uczeń Zenona.

40 Por. De anima 25, 9, CCL 2, 821.

41 Tamże 27, 1, CCL 2, 822-823: „Immo simul ambas et concipi et confici, profici dicimus, sicut et promi, nec ullum intervenire momentum in conceptu quo locus ordinetur", thum. Michalski, ALP I 241.

${ }^{42}$ Tamże 27, 2-3, CCL 2, 823: ,[...] si disiunctio simul utrique substantiae accidit per mortem, hoc debet coniunctionis forma mandasse pariter obvenientis per vitam utrique substantiae. Porro 
Według naszego autora poczęcie duszy i poczęcie ciała dokonuje się jednocześnie - konkretnie w momencie zapłodnienia. Należy rozróżnić jednak poczęcie duszy i poczęcie ciała, gdyż są dwie materie zapładniające, dwa rodzaje nasienia:

„W istocie odróżniając czas inseminacji musielibyśmy przyjąć także dwie różne materie (zapładniające) na podstawie różnicy czasów. Chociaż bowiem przyjmiemy dwa rodzaje nasienia: cielesne i duchowe (psychiczne), to uznajemy, że są one nierozdzielne i dlatego wspólczesne dla tej samej chwili, ${ }^{43}$.

Sposób, w jaki dochodzi do poczęcia istoty żywej wraz z duszą i ciałem, wprawdzie $\mathrm{z}$ różnych nasion, ale $\mathrm{w}$ jednym momencie, Tertulian przedstawia następująco:

„Otóż w zwykłym akcie płciowym, w którym mężczyzna łączy się z kobietą we wspólnym pożyciu, jak wiadomo, współdziala jednocześnie i dusza i ciało: dusza pożądając, ciało działając, dusza instynktownie, ciało aktywnie. $\mathrm{W}$ jednoczesnym zatem porywie dwojga ludzi, z których każdy doznaje wstrząsu, musuje nasienie całego człowieka czerpiąc $\mathrm{z}$ substancji cielesnej wilgoć, $\mathrm{z}$ substancji duchowej (psychicznej) ciepło [...] Czyż nie czujemy, że coś uchodzi z duszy [...]. To właśnie będzie nasienie duchowe (psychiczne) sączące się z duszy, jak ta ciecz - nasienie cielesne $\mathrm{z}$ ciała" ${ }^{44}$.

Proces ten, w ujęciu Tertuliana, jest niczym innym, jak odwzorowaniem stworzenia pierwszego człowieka, gdzie muł ziemi, z jakiego utworzone zostało ciało Adama, stanowi zaczątki nasienia cielesnego; natomiast tchnienie Boga, ciepło powietrza (vapor spiritus), $\mathrm{z}$ jakiego powstała dusza, stanowi zaczątki nasienia duchowego ${ }^{45}$ :

„[...] na samym więc już początku dwie różne i oddzielne substancje, muł i tchnienie, zlały się w jednego człowieka, mieszając $w$ jedno swoje nasiona, przekazując przez to sposób rozmnażania się rodzaju ludzkiego. Dlatego i teraz obie, choć tak odmienne, jednocześnie wypływają $z$ człowieka $i$ jednocześnie zasiane na odpowiedniej glebie, jako owoc obu substancji wydają człowieka, w którym znów

vitam a conceptu agnoscimus, quia animam a conceptu vindicamus; exinde enim vita, quo anima", thum. Michalski, ALP I 241.

${ }^{43}$ Tamże 27, 4, CCL 2, 823: „Immo si tempora seminum dividentur, et materiae diversae habebuntur ex distantia temporum. Nam etsi duas species confitebimur seminis, corporalem et animalem, indiscertas tamen vindicamus et hoc modo contemporales eiusdemque momenti", thum. Michalski, ALP I 241.

44 Tamże 27, 5-6, CCL 2, 823: ,In hoc itaque sollemni sexuum officio quod marem ac feminam miscet, in concubitu dico communi, scimus ut animam et carnem simul fungi, animam concupiscentia, carnem opera, animam instinctu, carnem actu. Unico igitur impetu utriusque toto homine concusso despumatur semen totius hominis habens ex corporali substantia humorem, ex animali calorem [...] nonne aliquid de anima quoque sentimus exire [...]. Hoc erit semen animale, protinus ex animae destillatione, sicut et virus illud corporale semen ex carnis defaecatione".

${ }^{45}$ Por. tamże 27, 7, CCL 2, 823. 
zawiera się nasienie, stosowne do rodzaju, jaki ustanowiony został dla poszczególnych płci"46.

Według przedstawionej powyżej teorii poczęcia, męskie nasienie składa się $z$ dwu elementów: jednego cielesno-wilgotnego i drugiego psychiczno-ciepłego. Jak zaznacza M. Menghi ${ }^{47}$, Tertulian jest tu wierny arystotelesowskiej, a także stoickiej koncepcji poczęcia, że męskie nasienie zawiera w sobie wszystko, co jest potrzebne do powstania embrionu. Także Soranos twierdzil, że łono kobiety, jest jedynie pojemnikiem dla męskiego nasienia ${ }^{48}$. Słusznie jednak zauważa J.H. Waszink ${ }^{49}$, że w innych utworach Tertulian przedstawia odmienną teorię, na przykład w De carne Christi mówi o poczęciu istoty żywej ze skrzepnięcia menstruacyjnej krwi kobiety $z$ nasieniem męskim ${ }^{50}$. Nawiązuje tu do innej arystotelesowskiej teorii poczęcia, powszechnej także w jego czasach, według której embrion otrzymuje „formę" $z$ nasienia męskiego, a „materię" $z$ menstruacyjnej krwi kobiety ${ }^{51}$.

7. Ustaliwszy, że „dusza zostaje zasiana w tym samym i z tego samego człowieka, i że od samego początku nasienie duszy jak też nasienie ciała jest

${ }^{46}$ Tamże 27, 8, CCL 2, 824: „Cum igitur in primordio duo diversa atque divisa, limus et afflatus, unum hominem coegissent, confusae substantiae ambae iam in uno semina quoque sua miscuerunt atque exinde generi propagando formam tradiderunt, ut et nunc duo, licet diversa, etiam unita pariter effluant pariterque insinuata sulco et arvo suo pariter hominem ex utraque substantia effruticent, in quo rursus semen suum insit secundum genus, sicut omni condicioni genitali praestitutum est".

${ }^{47}$ Por. M. Menghi, Tertulliano. L'anima, Venezia 1988, 239, przypis 231.

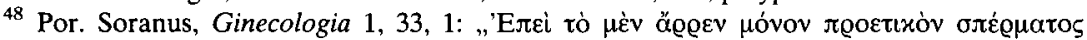

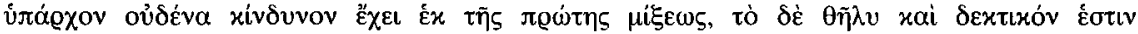

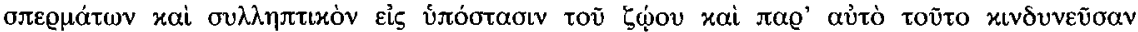



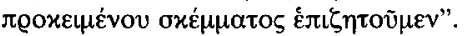

49 Por. J.H. Waszink, Tertullianus. De anima, Amsterdam 1947, 344.

50 Por. De carne Christi 19, 18-25, CCL 2, 907-908: „Negans autem ex carnis [quoque] voluntate natum [cur] non negavit etiam ex substantia carnis. Neque enim, quia ex sanguine negavit, substantiam carnis rennuit, sed materiam seminis, quam constat sanguinis esse + colorem, ut despumatione mutatum in coagulum sanguinis feminae. Nam ex coagulo + in caeso eius substantiae est, quam medicando constringit, id est lactis.Intellegimus ergo ex concubitu nativitatem domini negatam, quod sapit et <'non> ex voluntate viri et carnis', <idest> non ex vulvae participatione".

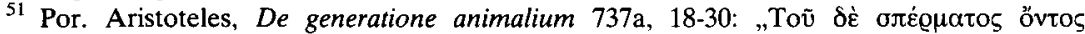



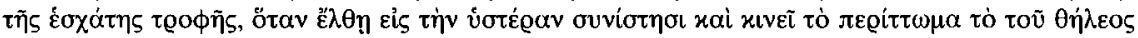

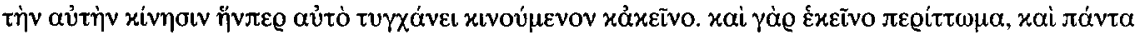

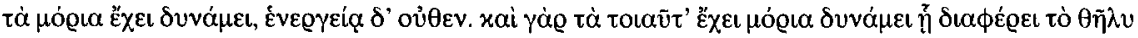

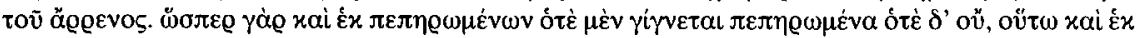

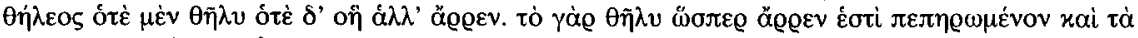

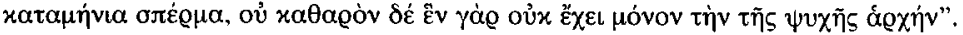


jedynym w całym szeregu pokolenia ludzkiego" 52 , Tertulian wskazuje, że ma to swoje konsekwencje w płci człowieka. Zagadnienie to podejmuje w 36 rozdziale De anima, stwierdzając, że dusza i ciało otrzymują płeć równocześnie w momencie zapłodnienia. Dopuszczenie różnicy czasowej w zapłodnieniu nasion substancji ciała lub duszy mogłoby dawać podstawy do sądzenia, że to ciało wyciska płeć duszy lub dusza ciału, co jest nieprawdą:

„Dusza zapłodniona (zasiana) w macicy wraz z ciałem, razem z nim także otrzymuje płeć. Dzieje się to jednocześnie, tak że ani jedna ani druga substancja nie leży u podstaw plci. Gdyby bowiem ich poczęcie dopuszczało jakąs przerwę pomiędzy nasionami obu substancji, tak że najpierw zapłodnione zostałoby albo ciało albo dusza, to można by także właściwość płci przypisać jednej z dwu substancji na skutek czasowej różnicy nasion. Wówczas albo ciało duszy, albo dusza ciału wyciskalaby płeć" ${ }^{53}$.

Tertulian kwestionuje poglądy Apellesa i Filumeny, jakoby dusze były męskie i żeńskie zanim polączą się z ciałem, wobec czego to ciało otrzymywałoby płeć od duszy ${ }^{54}$. według Kartagińczyka nie mają racji także ci, którzy przesądzają o płci duszy na podstawie ciała, twierdząc, że dusza łączy się z ciałem dopiero po jego narodzeniu ${ }^{55}$. Według Tertuliana zatem płeć jest wynikiem działania natury, które równocześnie zaznacza się na nasionach ciala i duszy:

„Nierozłączne nasiona obu substancji i ich zlanie w jedno podlegają powszechnemu wydarzeniu płci, jakiego to rozróżnienia dokonuje prawidło natury jakiekolwiek by ono było" 56 .

Autor nie rozstrzyga, o jakie prawa natury tu chodzi, ale podejmując zagadnienie płci tym bardziej podkreśla jednoczesne powstawanie ciala i duszy w momencie poczęcia człowieka, by odeprzeć wszelkie próby zanegowania takiego stanowiska ${ }^{57}$.

52 Por. De anima 36, 1, CCL 2, 838: „Constitueramus animam in ipso et ex ipso seri homine et unum esse a primordio semen, sicut et carnis, in totum generis examen".

53 Tamże 36, 2, CCL 2, 838: „Anima in utero seminata pariter cum carne pariter cum ipsa sortitur et sexum, ita pariter, ut in causa sexus neutra substantia teneatur. Si enim in seminibus utriusque substantiae aliquam intercapedinem eorum conceptus admitteret, ut aut caro aut anima prior seminaretur, esset etiam sexus proprietatem alteri substantiae adscribere per temporalem intercapedinem seminum, ut aut caro animae aut anima carni insculperet sexum".

54 Por. tamże 36, 3, CCL 2, 838. Apelles - uczeń Marcjona; na jego temat w kontekście gnozy, zob. J. Quasten, Patrologia, I, Casale Monferrato 1980, 268-270. Filumena, kobieta związana z Apellesem, zob. Tertullianus, Adversus Marcionem III 11, CCL 1, 522-523; De praescriptione haereticorum 6, 19 i 30, CCL 1, 191; De carne Christi 6, 2-4, CCL 2, 883-884.

${ }_{55}$ Tertulianowi chodzi tu prawdopodobnie o stoików, por. De anima 36, 3, CCL 2, 838; 25, 2 , CCL 2, 819.

56 Tamże 36, 4, CCL 2, 839: „Utriusque autem substantiae indiscreta semina et unita suffusio eorum communem subeunt generis eventum, qua lineas duxerit quaecumque illa est ratio naturae".

57 Por. Menghi, Tertulliano, s. 243, przypis 278. 
8. Teoria o pochodzeniu wszystkich dusz od jednej duszy prarodzica i o przekazywaniu duszy dzieciom przez rodziców nazywana jest traducjanizmem. Stoi ona w sprzeczności z doktryną kreacjonizmu o bezpośrednim stwarzaniu poszczególnych dusz przez Boga ${ }^{58}$. Tertulian wyprowadzał dusze $\mathrm{z}$ materialnego nasienia, wobec czego jego traducjanizm określany jest jako materialistyczny, w odróżnieniu do traducjanizmu spirytualistycznego (generacjonizmu) $)^{59}$, z którym spotykamy się u św. Augustyna ${ }^{60}$. Biskup Hippony opowiadał się wprawdzie przeciwko stanowisku, jakie prezentował Tertulian ${ }^{61}$, ale nie potrafił opowiedzieć się przeciw generacjonizmowi, przedstawiając, że dusza dziecka pochodzi od duszy rodzica, ale w sposób niematerialny i tajemniczy ${ }^{62}$; obraz ten jednak nie dawał odpowiedzi na wszystkie pytania ${ }^{63}$. Mimo wątpliwości Augustyn nie potrafił też przyjąć teorii kreacjonizmu ${ }^{64}$, która od św. Hieronima była coraz powszechniejsza, ale wydawała się nieść niebezpieczeństwo niemożliwości przekazywania grzechu pierworodnego; pozostawił tę kwestię otwartą ${ }^{65}$.

58 Por. C. Bove, Creazionizmo, ECat IV 827-828.

59 Por. G. Oggioni, Traducianismo, ECat XII 414-416. Odrębny problem stanowi kwestia, czy Tertulian był materialistą, skoro głosił także cielesność duszy. Należy jednak pamiętać, że Tertulian nigdy nie uważał materii za odwieczną i za prazasadę bytu, to przecież Bóg jest Stwórcą wszystkiego. Głoszona natomiast przez Kartagińczyka za stoikami corporalitas - cielesność oznaczała po prostu podstawę istnienia bytów (coś, co nie jest cielesne, po prostu nie istnieje; stąd też według Tertuliana jak istnieje corpus carnis tak też corpus animae.

${ }^{60}$ Por. Augustinus, De libero arbitrio III 20-21, CCL 29, 307-312; De Genesi ad litteram X 11 26, PL 34, 415-428; Epistula 166; 190, PL 33, 720-733; Retractationes II 45, CCL 57, 126-127; II 56, CCL 57, 135-136.

${ }^{61}$ Por. Augustinus, Epistula 190, 14, PL 33, 861: „nam et illi, qui animas ex una propagari adserunt, quam Deus homini primo dedit, atque ita eas ex parentibus trahi dicunt, si tertulliani opinionem sequuntur, profecto eas non spiritus sed corpora esse contendunt et corpulentis seminibus exoriri, quo perversius quid dici potest?".

${ }^{62}$ Por. tamże 190, 15, PL 33, 862: „tamquam lucerna de lucerna accendatur et sine detrimento alterius alter inde ignis existat, sic anima de anima parentis fiat in prole vel traducatur in prolem".

63 Tamże: „utrum incorporeum semen animae sua quadam occulta et invisibili via seorsum ex patre currat in matrem, cum fit conceptus in femina, an, quod est incredibilius, in semine corporis lateat; cum autem fluunt inrita sine ullis conceptibus semina, utrum semen animae non simul exeat, an summa celeritate atque atomo temporis, unde exierat, recurrat, an pereat; et si perit, quo modo ipsa, cuius mortale semen est, inmortalis est anima, an inmortalitatem tunc accipit, quando formatur, ut vivat, sicut iustitiam, quando formatur, ut sapiat; et quo pacto Deus eam fingat in homine, etiamsi anima seminaliter trahatur ex anima, sicut fingit in homine corporis membra, quamuis corpus seminaliter trahatur ex corpore [...]".

${ }^{64}$ Por. Epistula 166, 8, PL 33, 731-732: „nam licet nemo faciat optando, ut verum sit, quod verum non est, tamen, si fieri posset, optarem, ut haec sententia vera esset”.

65 Por. Oggioni, Traducianismo, ECat XII 414-416. Na temat grzechu pierworodnego u sw. Augustyna zob. A. Zurek, „Początkiem grzechu pycha” - Geneza grzechu Adama wediug sw. Augustyna, ŹMT 12, Kraków 1999, 101-107; A. Eckmann, Grzech pierworodny jako źódlo cierpień człowieka u Sw. Augustyna, ŹMT 12, Kraków 1999, 109-125. 
9. Tertulian w swoich rozważaniach położył nacisk na twierdzenie, że substancja duszy i ciała jednocześnie biorą początek w akcie poczęcia. Menghi zaznacza, iż było to ważne, aby na wszelkie sposoby uniknąć dania jakichkolwiek argumentów dla zwolenników metempsychozy. Teoria metempsychozy przedstawiała bowiem realne zagrożenie dla nauki o zmartwychwstaniu ciał ${ }^{66}$. Istotnie, Tertulian występuje zdecydowanie przeciwko takim poglądom poddając je krytyce i wykazując ich niedorzeczność. Poglądy Kartagińczyka na temat metempsychozy, a także wzmiankowanego powyżej grzechu pierworodnego mogą być przedmiotem odrębnych badań. Podsumowując całość rozważań jasno możemy jednak stwierdzić, że Tertulian rozumial człowieka jako byt złożony z ciała i duszy, dwu odrębnych substancji wzajemnie się dopełniających. Dusza jako tchnienie Boga, ożywia ciało już w momencie poczęcia. Embrion jest żywym organizmem złożonym z ciała i duszy, przekazywanej przez rodziców na drodze traducjanizmu. Aborcja jest zwykłym zabójstwem, dopuszczonym jedynie w przypadku ratowania życia matki wobec zaistniałych komplikacji porodowych.

\section{THE TERTULLIAN'S VIEW OF BEGINING HUMAN LIFE AND ABORTION}

(Summary)

This dissertation takes analyses of Tertullian's treatise On the Soul in aspects of beginning human life and abortion in context of ancient Greek philosopher's opinions. The article shows arguments which Tertullian used to prove that embryo have a soul so is alive and human life begins in moment of conception so man is not only body and is not only soul but is substantial union of flesh and corporal soul. The article also presents pronounces about conception of soul from psychical semen (Tertullian as tarducianist) and about abortion which Tertullian calls crime but permits as necessary in case when bad laying child could become killer of own mother during birth.

${ }^{66}$ Por. Menghi, Tertulliano, s. 239, przypis 229. 